\title{
The Shifting Relationship between Vocational and Higher Education in France and Germany: towards convergence?
}

\author{
Justin J. W. Powell, Lukas Graf, Nadine Bernhard, Laurence Coutrot \& \\ Annick Kieffer
}

\section{Comparing Skill Formation in France and Germany}

For decades, the skill formation systems in France and Germany have been analysed as contrasting cases because of institutionalised differences in educational values, norms, and governance, as well as in labour markets. This comparison follows the logic of difference, comparing dissimilar skill formation systems in centralist France and federalist Germany. 'Much of this cross-national variance has been explained in terms of the institutionalization of vocational education' (Brauns, 1999, p. 57; see also Deissinger, 2001; Culpepper, 2003). But higher education also differs considerably (Ben-David, \{1977\} 1992; Clark, 1983; Goldschmidt, 1991). Many typologies of vocational education and training (VET) and higher education (HE) summarise these differences. However, not only are national skill formation systems affected by the emerging European model of education via the Bologna and Copenhagen Processes (Powell, Bernhard \& Graf, 2012), but the French and German political economies have also been greatly reconfigured in the last two decades (Palier \& Thelen, 2010). Comparing the present situation, we ask whether traditional education and training typologies continue to be valid. While they have served as useful heuristic devices, they may hinder recognition of contemporary institutional changes, especially incremental changes that may nevertheless be transformational because of endogenous reforms and exogenous pressures due to Europeanisation. Do these typologies continue to reflect these systems as they evolve? To what extent have the key characteristics of skill formation systems in France and Germany changed, exemplified in the relationship between VET and HE? Have these countries converged?

Skill formation systems are affected by national developments and, increasingly, by the Bologna (HE) and Copenhagen (VET) Processes. The efforts of decision-makers to achieve goals of economic competitiveness and social inclusion imply the reform of historically evolved skill formation systems that are embedded in a national political-economy. We compare the vocational and higher education systems in France and Germany as they implement endogenous reforms and respond to the Bologna and Copenhagen initiatives. The effects of European policies seem to go deeper in Germany than in France, yet it is too early to measure all the (un)intended consequences of on-going internationalisation and Europeanisation processes. Analyses of the institutionalisation dynamics must consider the vocational/HE nexus if the relevance of Europe-wide standards and policies and more or less persistent national structures and pathways are to be understood (Powell \& Solga, 2010, 2011). Distinguishing between ideational, normative, and regulative dimensions (Scott, 2008) helps to clarify whether the changes affect underlying principles, lead to true standardisation or remain recommendations within the non-binding ('soft law') Open Method of Coordination. Both 
France and Germany are affected by Europeanisation as the 'voluntary participation of 1999 slowly evolved into a system of monitored coordination' (Ravinet, 2008, p. 365), exemplified in the Bologna and Copenhagen Processes. Some argue that they have intensified the 'blurring of boundaries' between vocational training, universities, and high-level professional preparation (grandes écoles) in France or in the vocational academies (Berufskademien) in Germany (Witte et al., 2008; Graf, forthcoming).

However, a range of typologies often emphasises enduring contrasts between France and Germany in VET and HE. Greinert (2005) presented a typology of three 'classical' models in European VET: the state-regulated bureaucratic model (France), the dual-corporatist model (Germany), and the liberal market economy model (UK). The French system was described as strongly centralised and regulated, planned, controlled, and financed by the State. Private interests were less important, especially since vocational education was mainly organised in full-time schools (although companies pay an apprenticeship tax). The primacy of politics was omnipresent. Didactical principles were mainly based on science and general academic education. In this ideal-typical typology, Germany was characterised by extensive mediation and coordination among state employers and labour representatives in an autonomous system of vocational training. Implicitly, most refer to the 'dual system' in which students alternate between school- and firm-based training. Here, the core principle is that of the vocation (Beruf) to be developed in practice (Deissinger, 2001, Kraus, 2007).

Studies of higher education often compare Germany, France, the UK, and the US. Theories suggesting one global tertiary system are questionable, Goldschmidt (1991) found, given the range of national HE systems that show 'administrative centralism' in France versus 'politicised legalism' in Germany. Ben-David ([1977] 1992) emphasised that France offered continuity between schooling and HE based on one scale of educational excellence, whereas Germany clearly divided schooling, VET, and HE. If the raison d'être of $\mathrm{HE}$ is similar - to select and educate an intellectual élite (Ben-David, [1977] 1992, p. 73) — these countries' HE systems maintain dissimilar structures to do so, with the French system more highly differentiated and with explicit 'élite' training in the prestigious professional schools (grandes écoles).

A key factor sustaining such differences is the fit between qualifications and labour markets. In The Social Foundations of Industrial Power: A Comparison of France and Germany, Maurice, Sellier and Silvestre (1986) compared these countries' training systems and work practices. They showed that German VET was firmly established and rather autonomous from state intervention, whereas French VET was less developed and more dependent on state involvement. The occupational position of German employees depends on general educational attainment but even more so on their specific apprenticeship training or learned vocation. Hence, the workforce has been stratified according to vocational and professional qualifications. Employment mobility occurs within this 'qualificational space'. In contrast, the French workforce has been stratified according to general and vocational education attainment (vocational diplomas), but also job experience. The divide between skilled and unskilled workers is paramount. French employment mobility is directly affected by the attainment of specific credentials. Access to intermediate positions results from successive job experiences in firms, with transitions and mobility occurring in the 'organisational space' of the firm. 
Recent Europeanisation processes in HE and VET demand that we revisit these comparisons to understand whether they still capture the essence of these systems.

\section{Institutional Shifts in VET and HE in France}

When comparing general education and vocationally-oriented education idealtypically, the differences between France and Germany are considerable. The distinction between VET and HE in France is less clear cut, since vocational education also takes place largely in HE. Nevertheless, the dominant ideals and goals of general education are the educated personality, self-control, autonomy, equality, and élite formation, whereas, in VET, general and occupational competences are more important. If in general education the orientation in defining learning goals and curricula is towards a canon of representative knowledge and science, for VET it is occupationally-specific knowledge, the labour market and economic demands, and qualified workers. Traditionally employed personnel are professionalised civil servants in both organisational fields and the status of learners are much the same, except for apprentices (a growing minority) who often spend more time in firms. The organisation of learning in general education is theoretical, whereas in VET it remains mainly school-based and technical, with both theory and practical experiences provided in that setting. Public administration remains a major actor. In terms of supervision, quality control, and governance, the State retains control over general education, while, in VET, regional government and corporatist influence counterbalance the strength of the Ministry. Similarly in finance, whereas general education is publicly funded, apprenticeship taxes in VET complement mostly public funds. Affecting these ideal-typical institutional characteristics, institutional change has taken place in the last decades that has shifted the relationship between VET and HE.

\section{Pathways into and within VET and HE}

Since the late 1950s, France has witnessed continuous debate about mass education - how to provide equal schooling to all children regardless of their social origins. They almost all attend a comprehensive and unified lower secondary school, the collège. At the end of the 'troisième' (age 15), they are streamed into general and technological or vocational pathways leading to the CAP (certificat d'aptitude professionnelle) and the BEP (brevet d'études professionnelles) or, since 1985, to a vocational baccalaureate (baccalauréat professionnel). Those who are oriented towards the 'general and technological' path follow a one-year partially common programme and are then divided into technological and general (academic) streams which, after two further years, lead to the corresponding baccalaureates.

The introduction of vocational baccalaureates made the baccalaureate the dominant educational goal in France (Beaud, 2002; Kieffer, 2008). Rising numbers of pupils attaining the vocational (from 3\% in 1990 to $19 \%$ in 2011) or technological baccalaureate (from $3 \%$ in 1970 to $16 \%$ in 2011 ) contribute to the massive overall expansion of the baccalaureate (from $20 \%$ in 1970 to $72 \%$ of a cohort in 2011) (Ministère de l'Education Nationale, 2012). This level has thus become less socially selective.

Although all baccalaureates officially grant access to HE, the kind of baccalaureate obtained matters because selection procedures vary accordingly — along with grades obtained (Bernhard, forthcoming). The general (academic) baccalaureate is the most prestigious, especially the scientific track (mathematics, physics), 
followed by technological and vocational baccalaureates (conceived as a steppingstone into the labour market) (Kieffer, 2008). The recent decision to shorten the four-year vocational baccalaureate programme by a year will probably exacerbate problems of access and survival in tertiary education.

The HE system in France has three main tracks: technological education for technicians and (some) engineers, universities, and prestigious professional schools (grandes écoles). Entrance to the grandes écoles still depends on a competitive examination for which students prepare in preparatory classes (classes préparatoires aux grandes écoles) for several years. Those with a general or technological baccalaureate have a clear competitive advantage. The share of baccalaureate holders per cohort has risen. But, as the education system changed, a new hierarchy was formed, reproducing educational and social stratification. Baccalaureate types, the meaning of honours, curricula, and organisational forms are all renewed social markers that determine life chances (Duru-Bellat \& Kieffer, 2008).

With minor exceptions, entry into $\mathrm{HE}$ is conditional on passing the baccalaureate. Besides the Diplôme d'Accès aux Etudes Universitaires (DAEU), which opens doors to the first year at university (for around 5,000 students per annum) (Ministère de l'Enseignement supérieur et de la Recherche, 2009), the 'capacité en droit' gives access to university law studies. Since 2002, certification of experiencebased competences (Validation des Acquis de l'Expérience, VAE) promises some permeability and attempts to reduce the number of uncertified workers by validating vocational experience. Anyone with at least three years of work experience can use VAE to obtain all types of nationally recognised qualifications. These alternative pathways still deliver a tiny share of the overall student population.

\section{Vocational Education and Training}

In France, technical and vocational education have been organised at national level since the 1880s (Tanguy, 1988). The CAP (Certificat d'aptitude professionnelle) has held a major historical role in education and collective agreements as a marker of skilled jobs. Jobs requiring this certificate are considered as skilled in the wage grid and bargaining agreements. It can be prepared in schools or apprenticeships where the time granted to general and vocationally-oriented topics varies. Each mode corresponds to different training institutions. The school-based vocational schools (lycées d'enseignement professionnel) are mostly operated under the supervision of the Ministry of Education. Apprentice Training Centres (CFA) are mostly run by Chambers of Industry, Commerce and Craft under the supervision of the relevant ministry (Education, Agriculture), but with strong involvement of corporate representatives and local actors. Here, students work part-time as apprentices in a firm to which they are bound by a work contract. Preparation for the CAP lasts for two years after the $3 \mathrm{rd}$ form of general secondary education. CAP certification remains selective since many students do not pass their final exams. Hence, many enter the labour market without any formal certification, suffering considerable risks.

The number of apprentices has steadily increased from 215,500 in 1992 to 407,809 in 2006-07 (Van de Portal, 2009). More recently, the number of participants in apprenticeships has also increased among students in HE. This trend towards the broader diffusion of apprenticeships among all levels of education results from a greater interest in providing all students with personal and practical experience of the workplace. Apprenticeships are most frequent at the CAP level; over half of all CAP certificates obtained in 2004 were obtained through this 
vocational track (Kieffer, 2008). Taking a CAP may be combined in various ways with a BEP (brevet d'études professionnelles) or (less frequently) a vocational baccalaureate. Recently, approximately $40 \%$ of all students who took a BEP also obtained a CAP. The BEP is now mostly used as a stepping-stone to the vocational baccalaureate; it was originally meant to offer an intermediate level certification between the CAP and the technological baccalaureate. Incremental reforms in the last half century have established a vocational educational ladder, corresponding to that of general education, with each step clearly defined: CAP, BEP, vocational or technological baccalaureate in the secondary segment; Brevet de technicien supérieur (BTS) at higher level technician training (Sections de techniciens supérieurs, STS), the tertiary technological certificate (Diplome universitaire de technologie, DUT) at the tertiary technological institutes (Instituts universitaires de technologie, IUT), and vocational bachelors (licence professionnelle) awarded by technological institutes (IUT) or universities.

France usually exemplifies centralised, state-dominated education and training, yet VET reforms have affected governance structures. The popular image of the 'state-regulated bureaucratic model' (Greinert, 2005) would be wrong if interpreted to assume the hegemony of the Ministry of Education at all times and in all places. Its role has been challenged through competition with other actors, regionalisation, and social partnership (Van Zanten et al., 1993). Since 1993, regions have taken charge of continuing education for youth aged 16-25. Incrementally, the 'regionalisation' process has increased the power of regions in VET, as they fund buildings, renovation, and equipment for vocational training schools; the central State's major role in VET is more regulatory than financial (Bel, 2001).

The involvement of corporate actors is too often underestimated. Management involvement in VET is exemplified by the Commissions professionnelles consultatives (CPCs). These bi-partisan committees in which management and union representatives as well as representatives from the relevant ministries work together to evaluate existing programmes, create vocational programmes and define training content and methods (référentiels) as well as the requirements for the corresponding certification. In addition, CPCs put emphasis on vocational experience in VET by demanding that teachers with a vocational background (5 years) be employed. Furthermore, state supremacy over awarding certificates, asserted under the Vichy government during WWII, has been challenged. The creation of in-firm certifications (certificats de qualification professionnelle, CQP) in continuing education may be taken as a sign of eroding state power over certification (Coutrot \& Lautman, 2005).

\section{Higher Education}

French tertiary education shows a clear hierarchy: the grandes écoles/university divide and the split between selective and non-selective segments. Both horizontal and vertical stratification have increased, despite educational expansion during the post-WWII period (Givord \& Goux, 2007). The grandes écoles constitute a group of highly selective and prestigious institutions that trains higher-level civil servants, professors and researchers, engineers, and company managers. Widely criticised, the university/grandes écoles divide is often blamed for the current crisis experienced by universities. The grandes écoles are accused of stealing the show, attracting the best students and confining universities to a subsidiary role. 
Many students enrol in universities after they have been refused access to a selective stream (CPGE, STS, IUT). However, the current university crisis also results from a lack of resources, multiple incoherent reforms, greater bureaucratisation, and lack of labour market forecasting (Beaud, 2002; Musselin \& Paradeise, 2009). Parallel to the Europe-wide three-cycle model of Bachelor's, Master's, and doctoral studies, the LMD (licence, master, doctorat) reform refers to the new sequences of degree programmes and involves shifts to a unitary credit system and from pass/fail exams to greater flexibility.

Because access to the grandes écoles is mostly limited to those who have spent one, two or three years in selective preparatory classes (classes préparatoires) and survived the highly selective contest (concours), only the top school achievers are likely to apply. Almost all CPGE students hold the general baccalaureate. Attending CPGE classes for 2 years provides access to certification equivalent to the first two years at university in the corresponding discipline. Students come from more privileged social and cultural backgrounds than regular university students.

Vocational tertiary education is diverse. The diplome universitaire de technologie (DUT), divided into 25 specialised sections (production or services), can be obtained in 115 tertiary technological institutes (instituts universitaires de technologie, IUT). The higher technician certificate (brevet de technicien supérieur, BTS) can be obtained in 106 specialties. BTS students prepare in high schools (lycées) or in higher level technician training programmes (sections de techniciens supérieurs). Recently, the 'vocationalisation of tertiary education', seen in the creation of a large number of vocational bachelor (B.A.) programmes (licences professionnelles), has advanced. Since 1999, more than 1,600 vocational bachelor (B.A.) programmes have been established, attracting approximately 40,000 students (Goulard, 2007). All include an internship in a firm for three or more months. Partnerships between firms and universities ensure a better match between local labour market demands for high-level VET and a smooth transition from HE to work (Giret, Guegnard, \& Michot, 2011).

But how should general and vocational education interface? Attempts to address this important question can be found in the roots of $\mathrm{HE}$ 'vocationalisation'. Tertiary technological institutes were established in the 1960 s, followed by further organisational forms and certificates. Thus, vocationalisation is no recent phenomenon resulting from the Bologna Process or Europeanisation (Agulhon, 2007), even if education is embedded in the EU Lisbon Strategy to improve economic competitiveness and even if the Bologna Process does emphasise economic utility ('employability' and labour market preparation) (Powell, Bernhard, \& Graf, 2012). While many are in favour of vocational certification, the organisational problems associated with this increasing demand for vocationalised B.A. programmes have made the system harder and harder to supervise by the Ministry of Education (Mignot-Gérard \& Musselin, 2001; Musselin, 2009). With the LMD reforms, vocationalised B.A. and two-year vocational M.A. programmes were created to replace the one-year maitrise followed by the vocationally-oriented certificate (Diplôme d'études supérieures spécialisées, DESS). The creation of this M.A. involved engaging non-academic practitioners to teach or manage these programmes, as in the IUT. Most vocationally-oriented M.A. programmes are more selective than research-oriented ones and graduates enjoy better labour market opportunities. 
French universities are changing. Whereas they used to be in charge of general education (except for law, medicine, and pharmacy), the grandes écoles offer vocational preparation of élites or middle-range technicians, while research is conducted primarily in separate research organisations. The vocationalisation of $\mathrm{HE}$ is making the boundary between $\mathrm{HE}$ and VET more fluid. Yet a large share of vocational preparation has always occurred in general schooling.

A fundamental shift occurred in 2007 when the Loi Pécresse or Loi relative aux libertés et responsabilités des universités (Academic Freedom and Responsibilities of Universities) (LRU) granted significant power to university presidents (Charle, 2008). Although universities have more financial autonomy, their degrees or diplomas are defined and certified at the national level (Vinokur, 2008). The aim of the LRU is to meet the demands of the 'knowledge economy' and bring French universities to the level of excellence of major international competitors.

Europeanisation's impact on recent reforms in France is challenging to assess (Musselin, 2009). Even before Bologna, the HE system was highly differentiated, so the LMD reforms could be easily implemented. Nonetheless, the reform has had an influence, such as the further vocationalisation of HE. Typical characteristics of the system persist. The grandes écoles are not fully integrated into the LMD process. They do not deliver licence degrees and the vocational two-year HE programmes (DUT, BTS) still exist, so that implementation has been largely shouldered by universities (Bernhard et al., 2010).

\section{Employment and the Education/Economy Nexus}

The French system is often characterised as a more moderately stratified system than the German one (Kerckhoff, 2000). Hence, it may not foreclose access to higher education as much as the German vocationally-oriented system (Shavit \& Müller, 1998, 2000), but this alone does not guarantee smooth and rapid schoolto-work transitions (Coutrot \& Kieffer, 2009, Duru-Bellat et al., 2010). Employment shifts affect expectations, such as problem-solving capacity, flexibility, firmspecific knowledge, and managerial qualities that demand new modes of interaction between corporations and education systems (Trottier, 2005). The frame of reference with regard to occupational careers in France remains the firm - more so than occupations, which require tighter cooperation at the education/ economy nexus.

CEREQ's 'Generation' surveys, in which 16,000 individuals were interviewed in 1992, 1998, and 2001, provide dynamic transition analyses. Although, over time, career trajectories equalise, those with higher education backgrounds obviously fare better. If $72 \%$ among the less qualified hold a job after 7 years, $86 \%$ of school-leavers and $93 \%$ of university degree holders are employed. Three-quarters of the interviewees changed employers at least once, yet a strong decrease in the number of fixed-term contracts and temporary jobs is notable, with differences by educational level (Couppié, Gasquet \& Lopez, 2006; CEREQ, 2002, 2007).

The design and organisation of the relationship between the education and production systems result from combinations of labour training, work organisation, coordination of work activities, and the ways in which industrial relations are managed and negotiated between the social partners (Maurice, Sellier \& Silvestre, 1986; Marsden, 1999). In France, this mode of coordination has been changing, 
but incrementally, to increasingly recognise the interests of firms in governance and reforms of education and training, especially because of the valorisation of the German 'dual system' model of apprenticeship (Verdier, 2008).

\section{Institutional Shifts in VET and HE in Germany}

In Germany, the division into general education and vocational education and training rests on the 'institutional logic of segregation' and the highly-stratified structure of secondary schooling which leads to limited permeability in the skill formation system (Powell \& Solga, 2011): whereas HE has as its dominant goal the development of personality, self-control, and autonomy, that of VET is to develop individual vocational competence and agency to carry out specific tasks. The orientation when defining learning goals and elaborating curricula is less a scientific approach guided by a canon of representative knowledge for general education than a perspective towards the labour market and its demand for qualified workers in the case of VET. Given its smaller size in comparison to France's, Germany's HE system focuses on training civil servants, professionals, and scientists.

The 16 German Federal States (Bundesländer) finance, control, and supervise the content and quality of general education. In VET, by contrast, corporatist self-administration is guided by federal regulations. Whereas in VET individuals are quasi-employees, in general education they are pupils or students. Typically, the organisation of learning combines theoretical education in schools and in-firm training. Compared to France, Germany emphasises the vocational principle. There is far less centralised state control in its corporatist mode of governance.

\section{Pathways into and within VET and HE}

In Germany, secondary schooling is highly stratified, and children continue to be streamed very early, after 4 or 6 years of schooling, among a variety of school types. The Hauptschulabschluss is obtained after nine or ten years. Today, half of the students leaving Hauptschulen find no training opportunity and instead participate in the pre-vocational training system, which also absorbs about $80 \%$ of school drop-outs (AG Bildung, 2008, p. 158). The intermediate secondary school-leaving certificate (Realschulabschluss / Mittlere Reife), obtained after ten years, has become the standard to access training opportunities and therefore skilled jobs (Solga, 2005). The highest secondary school level ends after 12 or 13 years (depending on the Bundesland), leading to the Hochschulreife, which gives access either to all $\mathrm{HE}$ institutions (Abitur) or to universities of applied sciences in the case of the Fachhochschulreife (Mayer, Müller, \& Pollak, 2007).

The VET system is made up of the pre-vocational training system (Übergangssystem), school-based vocational training, and the dual system proper (apprenticeship). Overall, students' general education level and choice of sector determine entry to specific VET fields due to educational stratification and occupational segmentation.

There are several pathways into HE, but only about $2 \%$ of all students begin their studies without a HE entry certificate. Another pathway is provided by vocationally-specific secondary schools (Fachoberschulen) or other vocational schools (Fachschulen), with about $14 \%$ of students beginning their studies after 
graduating from such schools (Heine, Schneider \& Sommer, 2008). Overall, alternative pathways remain marginal; upward permeability is lacking.

Another indicator of permeability is the share of tertiary students who already completed VET at upper-secondary level. Since reunification, the share of those students beginning their studies with a vocational-training certificate has dropped from a third to a quarter. Around half this substantial minority has completed vocational training, half after they obtained the necessary tertiary entrance certificate (Baethge, Solga \& Wieck, 2007). Thus, while fewer tertiary-level students have a basic vocational training certificate than in previous years, a sizable minority experiences multiple phases and types of skill formation.

In recognition of this, newer organisational forms and foci cater directly to such interests. Alongside the increasing internships completed by tertiary students in general academic courses, official dual study programmes combine in-firm vocational training of an apprenticeship with postsecondary-level teaching in a vocational academy (Berufsakademie), business college, university of applied sciences, or university (Powell \& Solga, 2011). These have steadily increased to around 850 programmes in 2010 (AusbildungPlus, 2010). They combine and alternate general academic education and in-firm praxis-based phases into a vocationally oriented academic programme. Although 28,525 students study at vocational academies (Berufsakademien) (KMK, 2008, 182ff.), such programmes remain quantitatively marginal and limited to certain Bundesländer (Busse, 2009).

\section{Vocational Education and Training}

In Germany, VET plays a far more significant role in preparing young adults for the labour market than in most European countries where general academic education is prime. The attraction of its VET system for other countries is due to the provision of highly-skilled workers, smooth transitions from school-to-work, and some insurance against the high youth unemployment rates that plague many other European countries (Regini, 1997; Verdier, 2008). Yet the dual system is no longer as successful in providing attractive training opportunities to the majority of a cohort leaving secondary schooling, in matching youth with firms offering stable career perspectives, or in providing youth from lower social backgrounds or from ethnic minority groups with work and social mobility. Indeed, the group of youth in state-funded, mainly school-based training in the 'pre-vocational training system' is nearly as large as that in apprenticeship training (Baethge, Solga \& Wieck, 2007). The demand for training has grown far beyond what firms provide. Especially less-educated youth are in danger of not successfully garnering a place in the dual system and are likely to remain at the margins of the labour market (Solga, 2008).

The pre-vocational training system has developed rapidly, so that each year about half a million young people do not enter regular vocational training and find themselves shunted into a range of pre-vocational programmes (Konsortium Bildungsberichterstattung, 2006) in which they are unlikely to acquire credits towards official qualifications. While these measures aim to enhance youth's work aptitudes, occupational orientations, or vocational preparation, this takes place outside the regular training system, often solely school-based and without the element of work experience in firms which is still expected by most employers. 
While the dual system has been upgraded, the tremendous costs of prevocational training indicate how highly institutionalised the idea of apprenticeships and the dual system is in Germany. In VET, all youth are expected to prepare for transition to labour markets, but these state-funded, school-based programmes reduce reform pressure on firms to provide apprenticeships.

The vocational principle (Berufsprinzip) is still an extremely stable parameter upon which the German VET system is built (Deissinger, 2001; Kraus, 2007). If firms fear losing valuable human capital, they also believe that vocational socialisation is best secured through firm-based training. And even the full-time vocational training schools (Berufsfachschule), which do not belong to the dual system proper, have integrated extended apprenticeship periods into the curriculum.

\section{Higher Education}

Higher education consists mainly of public universities and a few private graduate or professional schools. In 2009/2010, $409 \mathrm{HE}$ institutions enrolled 2.2 million students (Destatis, 2010). Students enter either a university focused on a general curriculum and science, or a university of applied sciences, which emphasises praxis-based education. Two-thirds study in 126 universities and equivalent institutions, nearly one-third are enrolled in 232 universities of applied science or (Fach-)Hochschulen (including administration colleges), and 1.5\% in 51 art and music colleges. Research universities offer a full array of academic subjects, attach importance to basic research, and award doctorates and the post-doctoral lecturing qualification (Habilitation). Admission requirements generally include the general $\mathrm{HE}$ entrance qualification (Abitur); sometimes admission is restricted by grades (Numerus clausus) or university selection processes. Universities of applied sciences, introduced in 1970/71, provide applied courses in such fields as economics, engineering, social work, public and legal administration and health and usually offer integrated semesters of practical training. Their professors must have both academic qualifications and professional experience.

German HE has been depicted as a system of 'political legalism' in which legal procedures dominate conflict resolution (Goldschmidt, 1991, pp. 5-6). Clark defines its governance regime as 'a combination of political regulation by the state and professional self-control by "academic oligarchies"' (Clark, 1983, p. 140). Four prominent 'traditional' features discussed by Teichler (2002, pp. 349-350) are that (1) universities are strongly oriented towards science; (2) universities are of more or less the same quality; (3) programmes usually lead to degrees that are oriented towards a vocation (see also Brauns, Müller \& Steinmann, 2002, p. 42); and (4) Länder governments steer HE (see also Mayer, Müller, \& Pollak, 2007). The 'German model' of HE gained prominence, based on both the Humboldtian ideal of a community of professors and students and on the principle of 'education as a public good' (as opposed to 'education as a commodity' and the principle of competition).

With regard to evolutionary dynamics, German $\mathrm{HE}$ is conservative, slowmoving, and inclined towards incremental rather than radical changes (Krücken, 2003; Teichler, 2005). Given this tendency towards inertia, recent rapid shifts in academic programmes, such as the widespread implementation of new degree structures (B.A./M.A.) throughout the country, represent an important case to study institutional change. Recent liberalisation raises questions about the future stability of its traditional mode of coordination, or regulation mode, in which 
collective decisions in state-subsidised organisations guide $\mathrm{HE}$ reforms (Graf, 2009). Decentralised reforms include the formalisation of the three-cycle degree structure, the introduction and retraction of tuition fees (up to $€ 500$ in some Länder), performance-based pay, greater autonomy for universities and university presidents, and the 'Excellence Initiative' that provides additional funds for research to selected organisations. As the HE sector is deregulated and New Public Management strategies gain a foothold, some claim that Germany has switched to a 'neo-liberal' market model in which universities acquire the status of organisational actors and reduce the power of the academic oligarchy (Krücken, 2007). However, this new 'marketisation' is not coterminous with Europeanisation (Powell, Bernhard \& Graf, 2012).

The implementation of the Bologna Process has been described as a large experimental 'field trial' with many unknown consequences and risks (Dobischat, Fischell \& Rosendahl, 2008, p. 97). According to Pritchard (2006, p. 112), 'the dialectic among global, national, and local forces will eventually hybridize German higher education into its own distinctive, new model'. The forceful implementation of the sequential degree cycle is linked to the Bologna reforms (KMK, 2007, p. 8). Traditional degrees like Magister, Diplom, and Staatsexamen have been gradually replaced (though not in all fields), leading to the parallel existence of old and new degrees. Often, in these new courses, 'competences and educational objectives are defined with a view to the demands of labor markets' (KMK, 2007, p. 11). Hence, the new B.A. programmes seem to be more vocationally-oriented (Krücken, 2007) and further elements of vocationally-specific training are being merged into previously academic general programmes through in-firm internships. Now, all types of higher education institutions offer similar certificates. These changes have altered the relationship between $\mathrm{HE}$ and VET, increasing competition between the two.

One important consensual goal of German education and training policy has been to make skill formation systems more flexible, more transparent, and more permeable, both within VET and more recently at the nexus between VET and $\mathrm{HE}$, as part of EU 'lifelong learning' initiatives (Bernhard, forthcoming). Among the developments that promise more permeability are qualification frameworks and credit transfer systems that increase transparency between the two sectors (Powell \& Trampusch, 2012).

\section{Employment and the Education/Economy Nexus}

Proponents of Germany's highly standardised and stratified educational system continue to emphasise that apprenticeship and a selective HE system help to achieve relatively low youth unemployment rates. However, youth unemployment has risen, despite the enviously low level compared to many other countries following the global financial crisis. Transitions have become less smooth, with only around two-thirds of youth entering full-time or part-time work in the first posttraining year (AG Bildung, 2008: Abb. H5.2-3). Overall, the duration of transition phases has increased, with over a third of successful apprenticeship completers not immediately transitioning into employment.

For $\mathrm{HE}$, the labour market demand for graduates has grown and continues to rise. Prospects for HE graduates are very good, indicated by their qualificationspecific unemployment rate at under 5\% since 1975 (AG Bildung, 2008: I2). Since 1993, the unemployment rates of those with and without an HE degree have 
diverged. Whereas the general rate in 2005 was $11.8 \%$, for $\mathrm{HE}$ graduates it was only $4.1 \%$ (AG Bildung, 2008). However, despite the 'academisation' of the educational and employment systems, the transition of HE graduates to a first job has become more complex and time consuming (Teichler, 2002, p. 366). By the mid-2000s, while the Bachelor's degree was implemented and the 'legal provision for a changed relationship between $\mathrm{HE}$ and the labor market was largely in place, mentalities and practices still needed to adjust . .' (Witte, 2006, p. 204). Human resources managers of leading enterprises launched the 'Bachelor Welcome!' campaign (BDA, 2004; BDI, 2005). Yet employers' lack of familiarity with these degrees and uncertainties about graduates' competences still pose challenges (Briedis, 2005, p. 48), affecting their transitions into labour markets (Alesi et al., 2005). As a result, four-fifths of the B.A. graduates from universities embark on further studies (three-fifths among B.A. graduates from universities of applied science) (KMK, 2007, p. 11). This reflects uncertainties about the value of the new degrees and skepticism among students (Dobischat, Fischell \& Rosendahl, 2008, p. 97). Although, most of those B.A. students who do not continue with further studies enter jobs considered traditional for HE graduates (KMK, 2007, p. 11), 'climbing the career ladder' in the first job is subject to a longer 'trial period' for Bachelor graduates than for Diplom graduates (Konegen-Grenier, 2004).

Even with these developments, employers still expect workers' qualifications to provide the source of well-matched competencies and job requirements instead of careers within internal labour markets. The relationship between VET and HE has adapted, but has not been fundamentally transformed, partly because Germany's industrial strength and export success continue, accompanied by the social partners' vested interests in VET (Culpepper \& Thelen, 2008) and highly-selective and stratified secondary schooling based on the vocational order. Divided and parallel systems of general, academic education and VET have grown, solidifying into what Baethge (2006) has termed the German 'educational schism'. This 'German exceptionalism' continues to exist despite recent Europeanisation (Powell \& Solga, 2011).

\section{Comparison and Outlook}

Acknowledging Europeanisation processes and endogenous reforms of education systems, we analysed the present situation of nationalVET and HE systems and their relationship in Germany and France. We asked whether the ideal-typical representations of prominent typologies that summarise key differences of postsecondary education and training systems and labour markets continue to adequately represent France and Germany. Here, we summarise whether several decades of institutional shifts have transformed these systems, or even led them to converge.

In France, several trends, such as regionalisation in education and the vocationalisation of $\mathrm{HE}$, indicate incremental processes of change over longer periods. We found few immediate reactions to external 'shocks' and limited direct implementation of European standards. In terms of pathways in VET, the traditional school-based route has recently been complemented by an increase in apprenticeship that went hand-in-hand with more participation of firms and social partners, as these corporate actors may increasingly claim responsibility for VET. The powerful Ministry of Education has been challenged. Due to regionalisation, the decision-making power and financing of skill formation by the French government have decreased, even if it retains regulatory authority (see Culpepper, 2003 on 
such 'decentralized cooperation'). Thus, the image of the state-dominated education and training system (Greinert, 2005) in which France exemplifies the 'stateregulated bureaucratic model' should not be misinterpreted; the Ministry of Education is not hegemonic. Furthermore, with the continuing process of vocationalisation of HE, the gap between HE and VET is even more blurred, especially in comparison with Germany where the boundary is still quite obvious and impermeable (Baethge, 2006) despite the newer, but still marginal, development of hybrid organisational forms (Powell \& Solga, 2010, 2011; Graf, forthcoming). The classification of France among countries with heterogeneous and differentiated HE systems is as true now as it has been for decades.

Regarding labour market transitions, the designation of France as an 'organisational space' seems to remain valid. The relative importance of past vocational experience is growing over schooling due to changes within the world of work (Tanguy, 2005; Trottier, 2005). Careers are largely based in organisations and do not depend as much on certificates as in Germany, which remains a 'qualificational space' although the increasing involvement of firms and of employers' organisations in the provision of VET programmes might change this relationship in the long run. Thus, the analysis by Maurice, Sellier, and Silvestre (1986) still offers a useful heuristic to compare these two countries, especially regarding the education/economy nexus and transitions from school-to-work (Shavit \& Müller, 2000, pp. 35-36).

Germany has long been known as a country with smooth school-to-work transitions, largely due to vocational training playing a far more significant role in preparing young adults for the labour market, oriented towards appropriate qualifications (Brzinsky-Fay, 2007). While the model of a successful pathway mainly refers to the dual system proper, it is no longer quantitatively the dominant pathway, even if it remains the ideal upon which the German model is based. We argue that the pre-vocational training system serves to maintain the logic of the German VET system, built on the 'vocational principle', by defending the traditional structures in VET as it reduces the pressure of the mismatch between training opportunities and youth seeking such apprenticeships. Yet this supplementary system diverts less-educated youth towards programmes that do not lead to equal qualifications; like in France, the less educated in Germany clearly suffer the greatest risks transitioning within training and into the labour market (Solga, 2008). If half of all lower secondary school-leavers cannot find training opportunities, this signals that a majorVET pathway has been transformed. Given this shift away from the investment of firms in training opportunities towards the provision of State training programmes (Baethge, Solga \& Wieck, 2007), we argue that the frequent typological classification of Germany as a country with a dominant 'dual system' must be reevaluated. Even if it functions as a prime source of skill formation upon which the German economy and wage structure depend, the preeminent VET model worldwide has been weakened.

While the German HE system has typically been defined as conservative, it has seen a number of reforms of considerable and lasting impact since the Bologna Declaration (1999). As one of the original four countries (like France) that devised and drove the Bologna Process, Germany has been in the forefront in implementing the reforms codified therein. Elements of vocationalisation are increasingly seen throughout the country, as many HE organisations and Federal States have interpreted the B.A. degree not so much as a general, liberal arts certificate, but, 
inspired by the vocational principle (Berufsprinzip) that is central to German conceptions of skill formation, as a specific degree ideally offering full vocational qualifications (Powell \& Solga, 2011).

Whereas German HE has quickly responded to and interpreted European goals and norms from its particular point view, French HE seems to have changed more through endogenous, longer-term pressures that began before Bologna and Copenhagen (Musselin \& Paradeise, 2009; Bernhard, forthcoming). Goldschmidt's (1991) distinction of France exhibiting 'administrative centralism' and Germany embracing 'politicized legalism' continues to have some credence. Similarly, Ben-David's ([1977] 1992) comparison of influential models in higher education continues to offer relevant insights, as access to tertiary education has not opened up to youth from lower-class backgrounds in either country (Duru-Bellat, Kieffer \& Reimer, 2008, 2010). Contemporary discourses of 'excellence' are found in both countries; remarkably, France has borrowed elements from the German 'Excellence Initiative' to improve its own standing, even as German HE looks to the French grandes écoles as a model of élite professional education. However, if these VET and HE typologies continue to capture important aspects of each system, none address the vocationalisation of $\mathrm{HE}$ and the rising importance of general education in training programmes, especially those related to information technology.

In Germany, the vocational academies offer hybrid courses of study that combine academic general education and in-firm training phases. But academic B.A. programmes also include internships and praxis-oriented elements such as 'soft skills' training that aim to prepare young adults for work in a variety of firms. Yet in contrast to the broad diffusion of B.A./M.A. programmes, new organisational forms at the nexus between VET and HE remain relatively marginal. Further research should focus on organisations that pioneer new pathways within and between the two organisational fields in skill formation (Graf, forthcoming).

In terms of transitions to labour markets, not only are they becoming less smooth in Germany, but also youth unemployment rates have climbed, even more so than for other age groups. By contrast, those who complete HE suffer the least risk of unemployment. This too challenges traditional views of German skill formation consisting of two parallel organisational fields that are relatively equal in terms of status and labour market outcomes.

At tertiary level in France, the gap between mass tertiary education and élite education provided by the grandes écoles remains important because a large share of the students who compete for upper management and higher civil servant positions is recruited from these organisations. In Germany, on the other hand, the distinction between universities and universities of applied science may have weakened, especially in discursive terms, due to marketing strategies and the introduction of B.A. and M.A. degrees in both organisational types. Such relationships will have to be further explored, especially as standardisation efforts, such as the European Qualification Framework (EQF), are fully developed and applied very differently across countries (Powell \& Trampusch, 2012).

Finally, both countries have evolved to become less like their original (idealtypical) models in VET and HE. As Verdier (2009) argues, France's slow shift from a wholly academic-oriented model to a more corporatist one (closer to the German model) seems to be occurring simultaneously with Germany's shift from a corporatist model to one in which the State plays a much more considerable role. The 
evidence provided here challenges the German myth of a well-functioning and dominant apprenticeship system that serves all youth who aspire to participate in it. Yet the apprenticeships offered in the French VET system are still quantitatively marginal in comparison, while the tertiary vocational courses in Germany (Berufsakademien) are few compared to the diversity of vocationally-oriented $\mathrm{HE}$ programmes in France (e.g., BTS, DUT or Licence pro). Thus, both endogenous reforms and exogenous pressures due to Europeanisation have led to institutional shifts, indicating that the two national skill formation systems have become more similar. This convergence due to incremental changes in both countries has also widened the distance between reality and ideal-types put forth in prominent typologies. Thus, while the traditional typologies that contrast France and Germany have served as useful heuristic devices, they need to be revised to represent these skill formation systems and the shifting relationship between vocational and higher education.

Fustin F.W. Powell, Research Unit 'Skill Formation \& Labor Markets', Wissenschaftszentrum Berlin für Sozialforschung (WZB), Reichpietschufer 50, D-10785 Berlin, Germany, powell@wzb.eu

Lukas Graf, Research Unit 'Skill Formation \& Labor Markets', Wissenschaftszentrum Berlin für Sozialforschung (WZB), Reichpietschufer 50, D-10785 Berlin, Germany, graf@wzb.eu

Nadine Bernhard, Research Unit 'Skill Formation \& Labor Markets', Wissenschaftszentrum Berlin für Sozialforschung (WZB), Reichpietschufer 50, D-10785 Berlin, Germany, bernhard@wzb.eu

Laurence Coutrot, Centre Maurice Halbwachs, École normale supérieure (ENS), 48 Bd Fourdan, 75014 Paris, France, laurence.coutrot@ens.fr

Annick Kieffer, Centre Maurice Halbwachs, École normale supérieure (ENS), 48 Bd Jourdan, 75014 Paris, France, annick.kieffer@ens.fr

\section{Acknowledgements}

This research was supported by grants from the EU Network on Economic Change, Quality of Life and Social Cohesion (EqualSoc) and the German Research Foundation (DFG) for the Project 'Internationalization of Vocational and Higher Education Systems in Transition (INVEST)'. We thank Christian Brzinsky-Fay, Christine Musselin and Heike Solga for helpful comments.

\section{REFERENCES}

AG Bildung (Autorengruppe Bildungsberichterstattung) (2008, 2010) Bildung in Deutschland 2008, 2010 (Bielefeld, Bertelsmann).

Agulhon, C. (2007) La professionnalisation à l'université, une réponse à la demande sociale? Recherche et Formation, 54, pp. 11-27.

Alesi, B., Bürger, S., Kehm, B. M. \& Teichler, U. (2005) Stand der Einführung von Bachelor- und Masterstudiengängen in Bologna-Prozess (Berlin, BMBF).

AusBiLdungPlus (2010) Suche nach dualen Studiengängen. www.ausbildungplus.de

Baethge, M. (2006) Das deutsche Bildungs-Schisma. SOFI-Mitteilungen 34.

Baethge, M., Solga, H. \& Wieck, M. (2007) Berufsbildung im Umbruch (Berlin, Friedrich-Ebert-Stiftung). 
BDA (2004) Bachelor Welcome! (Berlin, Bundesvereinigung der deutschen Arbeitgeber).

BDI (2005) Bachelor-/Masterstudiengänge in Deutschland (Berlin, Bundesverband der Deutschen Industrie).

BeAud, S. (2002) 80\% au Bac et après? Les enfants de la démocratisation scolaire (Paris, La Découverte).

BeL, M. (2001) Cadres institutionnels et rôle des organisations dans la construction de la formation professionnelle des jeunes, Education et sociétés, 7, pp. 37-50.

Ben-David, J. (\{1977\} 1992) Centers of Learning. Britain, France, Germany, United States (New Brunswick, NJ, Transaction).

BERNHARD, N. (forthcoming) Durch Europäisierung zu mehr Durchlässigkeit? Veränderungsdynamiken des Verhältnisses von beruflicher Bildung zur Hochschulbildung in Deutschland und Frankreich. Dissertation, Free University Berlin.

Bernhard, N., Graf, L. \& Powell, J. J. W. (2010) Wenn sich Bologna und Kopenhagen treffen. Erhöhte Durchlässigkeit zwischen Berufs- und Hochschulbildung, WZB-Mitteilungen, 130, pp. 26-29.

Brauns, H. (1999) Vocational education in France and Germany, International Fournal of Sociology, 28, pp. 57-98.

Brauns, H., MÜller, W. \& SteInManN, S. (2002) Expansion und Erträge tertiärer Bildung in Deutschland, Frankreich und im Vereinigten Königreich, Berliner Fournal für Soziologie, 12, pp. 37-62.

BRIEDIS, K. \& Minks, K.-H. (2005) Der Bachelor als Sprungbrett? Kurzinformation HIS, Hochschul-Informations-System, 6, pp. 39-48.

BRZINSKY-FAY, C. (2007) Lost in transition? Labour market entry sequences of school leavers in Europe, European Sociological Review, 23, pp. 409-23.

Busse, G. (2009) Duales Studium (Düsseldorf, Hans-Böckler-Stiftung).

CEREQ (2002) Quand l'école est finie. Premiers pas dans la vie active de la génération 2001. www.cereq.fr/pdf/QEEF2001.pdf

CEREQ (2007) Quand la carrière commence . . . Les sept premières années de la vie active de la génération 98. www.cereq.fr/carriere/QCC.pdf

Charle, C. (2008) La Loi LRU dans une perspective européenne, Mouvements, 3, pp. $94-101$.

Clark, B. (1983) The Higher Education System. Academic Organization in CrossNational Perspective (Berkeley, University of California Press).

Couppie T., Gasquet, C. \& Lopez, A. (2006) Les sept premières années de vie active de la Génération 98: entre insertion et début de carrière. www.cereq.fr/pdf/ b234.pdf

Coutrot, L. \& Kieffer, A. (2009) Improved opportunities and increased segregation: underlying tensions between vocational and general education in France, in: A. Hadjar \& R. Becker (Eds) Expected and Unexpected Consequences of the Educational Expansion in Europe and the U.S.A. (Bern, Haupt).

Coutrot, L. \& Lautman, J. (2005) Doctrines et pratiques patronales. L'adéquation: des pratiques de formations aux niveaux, in: J.-F. GIRET, A. Lopez \& J. Rose (Eds) Des Formations pour quels Emplois? (Paris, La Découverte).

Culpepper, P. D. (2003) Creating Cooperation: how States develop human capital in Europe (Ithaca, NY, Cornell University Press). 
Culpepper, P. D. \& Thelen, K. (2008) Institutions and collective actors in the provision of training, in: K. U. MAYER \& H. Solga (Eds) Skill Formation (Cambridge, Cambridge University Press).

Deissinger, T. (2001) Zur Frage nach der Bedeutung des Berufsprinzips als 'organisierendes Prinzip' der deutschen Berufsausbildung im europäischen Kontext: eine deutsch-französische Vergleichsskizze, Tertium Comparationis, 7, pp. $1-18$.

Destatis (2010) Hochschulen auf einen Blick (Wiesbaden, Statistisches Bundesamt).

Dobischat, R., Fischell, M. \& Rosendahl, A. (2008) Auswirkungen der Studienreform durch die Einführung des Bachelorabschlusses auf das Berufsbildungssystem (Düsseldorf, Hans-Böckler-Stiftung).

Duru-Bellat, M. \&. Kieffer, A. (2008) From baccalaureate to higher education in France: shifting inequalities, Population, 63, pp. 119-154.

Duru-Bellat, M., Kieffer A. \& Reimer, D. (2008) Patterns of social inequalities in access to higher education in France and Germany, International fournal of Comparative Sociology, 49, pp. 347-368.

Duru-Bellat, M., Kieffer, A. \& Reimer, D. (2010) Les inégalités d'accès à l'enseignement supérieur. Une comparaison entre l'Allemagne de l'Ouest et la France, Economie et Statistique, 433-434, pp. 3-22.

Giret, J.-F., Guegnard, C. \& Мichot, C. (2011) The vocationalisation of university programmes in France, in: H. Schomburg \& U. TeICHLER (Eds) Employability and Mobility of Bachelor Graduates in Europe (Rotterdam, Sense Publishers).

Givord, P. \& Goux, D. (2007) France: mass and class - persisting inequalities in postsecondary education in France, in: Y. Shavit, R. Arum \& A. Gamoran (Eds) Stratification in Higher Education (Stanford, CA, Stanford University Press).

GoldsCHMIDT, D. (1991) Idealtypische Charakterisierung sieben westlicher Hochschulsysteme, Zeitschrift für Sozialforschung und Erziehungssoziologie, 11, pp. 3-17.

GrAF, L. (2009) Applying the varieties of capitalism approach to higher education, European Fournal of Education, 44, pp. 569-585.

GRAF, L. (forthcoming) The Hybridization of Vocational Training and Higher Education in Austria, Germany, and Switzerland. Dissertation, Free University Berlin.

GreinerT, W.-D. (2005) Mass VET in Europe (Luxembourg, European Communities).

Goulard, F. (2007) L'Enseignement supérieur en France, état des lieux et propositions.

Heine, C., Schneider, H., Sommer, D. \& Willich, J. (2008) Studienanfänger im Wintersemester 2007/08. www.his.de/pdf/pub_fh/fh-200816.pdf

Kerckhoff, A. (2000) Transition from school to work in comparative perspective, in: M. Hallinan (Ed) Handbook of the Sociology of Education (New York, Academic).

KIEFFER, A. (2008) Applying the ISCED-97 to France: some issues and propositions, in: S. SCHNEIDER (Ed) The International Standard Classification of Education (Mannheim, MZES).

KMK (2007) Bologna-Prozess - Nationaler Bericht 2005 bis 2007 für Deutschland von KMK und BMBF (Bonn, Kultusministerkonferenz).

KMK (2008) The Education System in the FRG (Bonn, Kultusministerkonferenz). 
Konegen-Grenier, C. (2004) Akzeptanz und Karrierechancen von Bachelor- und Masterabsolventen deutscher Hochschulen, IW-Trends, 3, pp. 1-17.

Konsortium Bildungsberichterstattung (2006) Bildung in Deutschland (Bielefeld, Bertelsmann).

KRAUS, K. (2007) Die 'berufliche Ordnung' im Spannungsfeld von nationaler Tradition und europäischer Integration, Zeitschrift für Pädagogik, 53, pp. 382398.

KRÜCKEN, G. (2003) Learning the 'New, New Thing': on the role of path dependency in university structures, Higher Education, 46, pp. 315-339.

KRÜCKEN, G. (2007) Organizational fields and competitive groups in higher education: some lessons from the Bachelor/Master reform in Germany, Management Revue, 18, pp. 187-203.

Marsden, D. (1999) A Theory of Employment Systems. Micro Foundations of Societal Diversity (Oxford, Oxford University Press).

Maurice, M., Sellier, F. \& Silvestre, J. J. (1986) The Social Foundations of Industrial Power. A Comparison of France and Germany (Cambridge, MIT Press).

Mayer, K. U., Müller, W. \& Pollak, R. (2007) Germany: institutional change and inequalities of access in higher education. In: Y. Shavit, R. Arum \& A. Gamoran (Eds) Stratification in Higher Education (Stanford, CA, Stanford University Press).

Mignot-Gerard, S. \& Musselin, C. (2001) L'offre de formation universitaire: à la recherche de nouvelles régulations, Education et sociétés, 8, pp. 11-25.

Ministere de L'Education Nationale (2012) Résultats définitifs de la session 2011 du baccalauréat, Note d'Information 12.03 (Paris).

Ministère de L'Enseignement Supérieur et DE LA Recherche (2009) Note d'information 09.06. Paris.

Musselin, C. (2009) The Side Effects of the Bologna Process on National Institutional Settings: The Case of France, in: A. Amaral, G. Neave, C. Musselin \& P. MAASSEN (Eds.) European Integration and the Governance of Higher Education and Research (Dordrecht, NL, Springer).

Musselin, C. \& Paradeise, C. (2009) France: from invisible transitions to institutional change, in: C. Paradeise, E. Reale, I. Bleiklie \& E. Ferlie (Eds) University Governance: Western European Comparative Perspectives (Dordrecht, Springer).

Palier, B. \& Thelen, K. (2010) How Activation Policies and Welfare Reforms Contribute to the Dualisation of Coordinated Market Economies, Politics $\mathcal{E}$ Society, 38, pp. 119-148.

Powell, J. J. W., Bernhard, N. \& Graf, L. (2012) The Emerging European Model in Skill Formation: Comparing Higher Education and Vocational Training in the Bologna and Copenhagen Processes, Sociology of Education, 85, pp. 240-258.

Powell, J. J. W. \& Solga, H. (2010) Analyzing the Nexus of Higher Education and Vocational Training in Europe, Studies in Higher Education, 35, pp. 705-721.

Powell, J. J. W. \& Solga, H. (2011) Why are Higher Education Participation Rates in Germany so Low? Institutional Barriers to Higher Education Expansion, fournal of Education and Work, 24, pp. 49-68. 
Powell, J. J. W. \& Trampusch, C. (2012) Europeanization and the Varying Responses in Collective Skill Systems, in: M. Busemeyer \& C. Trampusch (Eds) The Political Economy of Collective Skill Systems (Oxford, Oxford University Press).

PRITChARD, R. (2006) Trends in the restructuring of German universities, Comparative Education Review, 50, pp. 90-112.

Ravinet, P. (2008) From voluntary participation to monitored coordination, European Fournal of Education, 43, pp. 353-367.

Regini, M. (1997) Different responses to common demands: firms, institutions and training in Europe, European Sociological Review, 13, pp. 171-189.

Shavit, Y. \& MÜller, W. (1998) From School to Work: A Comparative Study of Educational Qualifications and Occupational Destinations (Oxford, Clarendon Press).

Shavit, Y. \& MÜLlER, W. (2000) Vocational secondary education. Where diversion and where safety net? European Societies, 2, pp. 29-50.

Scotт, W. R. (2008) Institutions and Organizations (Thousand Oaks, CA, Sage).

SolgA, H. (2005) Ohne Abschluss in die Bildungsgesellschaft (Opladen, Verlag Barbara Budrich).

Solga, H. (2008) Lack of training, in: K. U. MAYer \& H. Solga (Eds) Skill Formation: Interdisciplinary and Cross-National Perspectives (Cambridge: Cambridge University Press).

TANGUY, L. (1988) L'enseignement technique et professionnel, repères dans l'histoire, Formation-Emploi, 27-28, pp. 5-15.

TANGuY, L. (2005) De l'éducation à la formation: quelles réformes? Education et sociétés, 16, pp. 99-122.

Teichler, U. (2002) Hochschulbildung, in: R. Tippelt (Ed) Handbuch Bildungsforschung (Opladen, Leske \& Budrich).

TeIchleR, U. (2005) Hochschulstrukturen im Umbruch (Frankfurt am Main, Campus).

Trottier, C. (2005) L'analyse des relations entre le système éducatif et le monde du travail en sociologie de l'éducation, Education et sociétés, 16, pp. 77-97.

Van De Portal, M. (2009) L'accueil des apprentis en formation supérieure, Revue française de gestion, 35, pp. 31-42.

Van Zanten, A., Plaisance, E. \& Sirota, R. (1993) Les Transformations du système éducatif (Paris, L'Harmattan).

Verdier, E. (2008) L'éducation et la formation tout au long de la vie, Sociologie et sociétés, 40, pp. 195-225.

Verdier, E. (2009) Lifelong Learning Regimes versus VET Systems in Europe. Paper presented at SASE conference 2009, Sciences Po, Paris.

Vinokur, A. (2008) Vous avez dit 'autonomie'? Mouvements, 3, pp. 72-81.

Witte, J. (2006) Change of Degrees and Degrees of Change. Dissertation, University of Twente.

Witte, J., Van Der Wende, J. \& Huisman, J. (2008) Blurring boundaries: how the Bologna Process changes the relationship between university and nonuniversity higher education, Studies in Higher Education, 33, pp. 217-231. 